\title{
Fraught with Friction: Inclusive Development for Informal Workers in Urban Ghana
}

\author{
Tanja D. Hendriks ${ }^{1} \cdot$ Rafael Verbuyst ${ }^{2} \cdot$ Mayke Kaag $^{3} \mathbb{D}$
}

Accepted: 23 January 2022 / Published online: 18 February 2022

(C) The Author(s) 2022

\begin{abstract}
Informal workers are a heterogeneous group distinguished by diverse activities and interests, but they have in common that they operate largely outside state regulations. In this article, we analyse the ways in which informal workers in Ghana are organising (themselves) in response to proposed relocations of their workspace. Borrowing from Tsing, we distinguish three layers of friction that can lead to (structural) change, collective action, and an increase in informal workers' political leverage. Our two case studies in Accra and Kumasi show how striving for inclusive development is a process shaped by diverse agendas and potentially conflicting interests. These relational and political aspects are crucial for understanding the frictions involved, as well as how these may lead to change. Where the tendency is to gloss over these frictions, we argue that they need to be the starting point for effective policies and initiatives for inclusive development.
\end{abstract}

Keywords Informal workers · Friction · Collective action · Political leverage · Transnational organising $\cdot$ Relocation $\cdot$ Ghana

\section{Résumé}

Les travailleurs et travailleuses informel-le·s constituent un groupe hétérogène qui se distingue par sa grande diversité d'activités et d'intérêts, mais qui a comme caractéristique commune le fait de fonctionner essentiellement en marge des réglemen-

Mayke Kaag

m.m.a.kaag@asc.leidenuniv.nl

Tanja D. Hendriks

t.d.hendriks@sms.ed.ac.uk

Rafael Verbuyst

verbuystr@gmail.com

1 Centre of African Studies, University of Edinburgh, 15a George Square, EH8 9LD Edinburgh, Scotland

2 Ghent University, 9000 Sint-Pietersnieuwstraat, Ghent, Belgium

3 African Studies Centre Leiden University, PO Box 9555, 2300 RB Leiden, The Netherlands 
tations gouvernementales. Dans cet article, nous analysons les différentes façons dont les travailleurs et travailleuses informel-le·s au Ghana s'organisent en réponse aux délocalisations proposées de leur espace de travail. En nous inspirant de Tsing, nous distinguons trois niveaux de tension qui peuvent conduire à un changement (structurel), à une action collective et à un poids politique accru des travailleur·euse-s informel·le·s. Nos deux études de cas à Accra et Kumasi montrent à quel point militer pour un développement inclusif est un processus façonné par des motivations diverses et des intérêts potentiellement conflictuels. Ces aspects relationnels et politiques sont cruciaux pour comprendre les tensions qui sont en jeu, ainsi que la manière dont elles peuvent conduire au changement. Alors que la tendance est de dissimuler ces tensions, nous soutenons qu' elles doivent au contraire constituer le point de départ de politiques et d'initiatives efficaces pour un développement inclusif.

\section{Introduction}

The informal economy hardly played a role in earlier development approaches that focussed on economic growth, as it was considered an impediment to progress due to its low productivity from a macro-economic perspective. However, shifts in development thinking putting well-being, redistribution and equality of opportunities and outcomes central (see the introduction to this special issue), have turned the informal economy into an important focus of efforts geared towards inclusive development. The latter can be defined as 'development that includes marginalised people, sectors and countries in social, political and economic processes for increased human well-being, social and environmental sustainability, and empowerment' (Gupta et al. 2015). But while it is acknowledged that inclusive development includes redistribution and thus is an inherently political process (Reinders, Dekker, Kesteren \& Oudenhuijsen 2019; Cloutier et al. 2021), inclusive development policies often still assume that identifying marginalised categories, and designing top-down policies for those target groups, will do the job (IMF 2012; ILO 2021; Utz 2021).

In this contribution, we will, however, argue that it is important, firstly, not to view such groups as passive victims of exclusion but to take their agency as a starting point; secondly, not to consider them in isolation but take the political aspect of inclusion and inclusive development seriously by paying attention to differential interests and political strategies within such groups and between them and other actors; finally, not to rely on top-down and linear thinking for achieving inclusive development (Green 2018), but to pay attention to the micro-processes that make up larger processes of change, in often unforeseen and unplanned ways. We will show that the concept of 'friction' as developed by Tsing (2005) is particularly useful to bring all these aspects to the fore, as it refers to how interactions by people acting from different positionalities and in sometimes antagonistic ways, holds the potential to produce structural change.

It may be clear that from a policy perspective, the informal sector is the manifestation par excellence of marginalisation and exclusion, namely from the visible 
and countable economy, from the reach of the state, from rules and regulations, and from participation in negotiations with the government and labour organisations. ${ }^{1}$ A perspective in and from the informal economy itself, however, reveals that it is a vibrant part of society in which people make a living and deploy strategies for being included, in solidarity networks and professional organisations, in partisan political networks that link them to the state and its resources, and in the larger (inter)national economy (cf. Bayat 2000; Lindell 2010). While policies tend to see informal workers as victims of exclusion and as such in need of being included, our contribution shows how informal workers are active agents vying for inclusion in processes, networks, and arenas that they themselves deem important.

In this paper, we specifically look at collective organising of informal workers in urban Ghana, and how they actively try to be included in decision making processes related to two proposed work space relocations. The two case studies show how the dynamics and outcomes of collective action are shaped by diverse agendas and possibly conflicting interests. We will argue that exactly these relational and political aspects are crucial for understanding the frictions involved in processes of more inclusive development. However, rather than taking the political and frictional aspect as something that is inherently negative as policy makers often tend to do (see also Ferguson 1994), we explore, based on Tsing (2005), whether and how these aspects can also be productive of positive structural change.

Anna Tsing coined the concept of friction, 'the awkward, unequal, unstable, and creative qualities of interconnections across difference' $(2005, \mathrm{p}$. 4), to enable research on global connections that imply a diversity of actors and several levels of scale, as well as power differences and diverging perspectives. Taking differences as a starting point, she emphasises 'that heterogeneous and unequal encounters can lead to new arrangements of culture and power' (Tsing 2005, p. 5). Friction is thus characterised by a productive potential that can effectuate change, whether structural or more short-term. Yet, friction can also produce continuity, leading to further entrenchment of the status quo-be it that this continuity is also provisional as change may become visible over time. Looking at the role of local, national, and transnational linkages and partnerships in the context of planned relocations of informal workers in urban Ghana through the lens of friction provides us with an opportunity to explore the ways in which differences are central to both enabling and impeding informal workers' organisations' ability to achieve collective action and exercise political leverage for inclusion.

\footnotetext{
1 Broadly, the informal sector refers to a wide variety of economic activities where workers do not enter into signed contracts or formal labour arrangements (Hart 2009; Lindell 2010). Activities and earnings are highly varied, but informal workers share a common characteristic: they have limited access to formal social security measures (informal workers' associations often do provide informal social security to their members) and their rights as workers are not formally recognised (Chen 2012; Lindell 2010; Theron 2010). However, the lines between the formal and informal economy are blurry and it is not uncommon for workers to be active simultaneously in both formal and informal arrangements. We consider informal workers to be those whose economic activities largely 'lie beyond or circumvent state regulation' (Lindell 2010: 5).
} 
This paper is based on data gathered during two separate but overlapping periods of ethnographic fieldwork in the Ghanaian cities of Accra and Kumasi as part of a larger project on political leverage of informal workers in Ghana and Benin, funded by The Netherlands Ministry of Foreign Affairs and implemented by the Netherlands Research Council (NWO) and the Knowledge Platform on Inclusive Development (INCLUDE). We carried out a total of four months of ethnographic fieldwork at Makola's 31st December Market in Accra and in Suame Magazine in Kumasi, which both featured attempts at exercising political leverage around potential relocations on behalf of informal workers' organisations and transnational partners. We refer to this as the politics of relocation (see below). Moreover, the comparison between the two cases is interesting as Accra and Kumasi have different municipal authorities and political contexts. Data were mainly gathered through participant observation and semi-structured interviews with informal workers, government officials, trade unionists and their international partners.

Our research took place in the lead up to the general election of 2016 and this impacted our fieldwork and findings. At the time, the National Democratic Congress (NDC) was in power and the New Patriotic Party (NPP) in the opposition. These two parties have been alternating power since 1992 and they also switched roles after the elections on 7 December 2016. Everyday issues became extremely politicised during the campaigns, which resulted in some tense conversations with informants, but overall people spoke candidly about (party) politics precisely because of this.

In the following, we start by introducing the case study sites and our methodology, followed by a discussion of organising in the informal sector, including the different types of organisations that are active in the Ghanaian context. We do this by delineating three layers of friction that shape informal workers' organising attempts. We then analyse how these layers present themselves in our two case studies, and what this means for the political leverage of the informal workers concerned. In the conclusion, we reflect on what our analysis may contribute to the larger question of policies for inclusive development.

\section{Organising Informal Workers in Urban Ghana}

Makola Market in Ghana's capital Accra is one of the country's oldest, biggest, and most congested markets. It consists of several different parts in which thousands of street vendors, traders, clients and tourists come together (Thiel 2015). Food, televisions, fish, cushions, cloth, cream, chairs and charcoal can all be found there. Successive governments have tried to relocate the market, at least partly or temporarily, in order for sturdier structures to be constructed. Over the course of four months (September-December 2016), the first author spent an average of three days a week conducting ethnographic fieldwork in the market; visiting, chatting and discussing with the approximately 200 textile traders. Regular informal conversations about their businesses, work environment, organisations and potential relocation plans were held with 40 traders, and 25 of them also agreed to in-depth interviews which lasted between 1 and $2 \mathrm{~h}$. In addition, the author attended union and market association meetings and conducted 37 additional semi-structured interviews with 
relevant government officials, NGO-staff, market leaders and union workers. At the time of fieldwork, the Accra Metropolitan Assembly (AMA) had proposed to transform Makola's 31st December market area into a '24-h entertainment building with casino's and banks and also nightlife', for which the traders would have to (temporarily) relocate.

Similar transformation plans have been unfolding in Kumasi, Ghana's second largest city. Suame Magazine, an industrial cluster that has previously known great economic prosperity, is home to thousands of informal auto mechanics who fix second-hand cars and machines. Some of them arrived 'when the whole place was still bush', but today, the area is overcrowded and its structures are dilapidated. The infrastructure no longer allows for expansion, but the influx of people is relentless. Shops and garages are springing up all across Kumasi and are no longer confined to the suburb of Suame. For some, relocating to a new site has become a 'life goal', they aim to (re)make Suame Magazine into an 'industrial hub', preferably with the financial assistance of international partners. Others want to stay and continue capitalizing on the cluster's current favourable (geographical) position. In August and September 2016, the second author made almost daily visits to the area to conduct themed informal conversations with the many workers and their representatives in Suame Magazine. The chaotic nature of the area makes it challenging to gauge its size and the workforce it hosts. Informants were therefore mostly chosen via the method of snowball sampling. Most of the people who consented to in-depth interviews were informal workers (both 'apprentices' and 'masters', with a focus on mechanics and spare parts dealers), leaders of organisations, NGO workers and consultants. The resulting 70 interviews usually lasted for about an hour, so as not to interfere too much with people's busy schedules.

As an unintended consequence of 'neoliberal policies and the decline in formal employment opportunities' (Lindell 2010, p. 2), urban landscapes are increasingly characterised by 'informal spaces' such as parts of Makola Market and Suame Magazine (Roy 2005, p. 155). Cities all across the African continent continue to grow rapidly, leading to pollution, congestion, and housing shortages (see Gillespie 2015; Kamete and Lindell 2010; Resnick 2011). This is also apparent in Makola Market and Suame Magazine, where large numbers of informal workers make a living: both places started out relatively small and in designated areas, but have increasingly engulfed their surroundings. In both cases, plans to relocate large groups of informal workers are well under way. So how do workers and their organisations in Makola Market and Suame Magazine organise collectively in order to have their say on these potential relocations, in order to be included in decision making processes, but also in the profits that possibly come with these new urban developments?

Scholars have increasingly become interested in the ways in which informal workers organise in order to protect their rights and interests (see Gillespie 2015; Lindell 2010). Achieving collective action and exercising political leverage is a daunting task: the environment is inherently competitive, and interests often diverge and impinge on each other. Increasingly, traditional ways of organising are supplemented by entering into transnational partnerships, for example with trade unions funded by international development actors (Lindell 2009). It is primarily this changing landscape of mobilisation that adds to the complexity of collective action on the ground. 
Bayat, who has written extensively on informal sector organising (1997, 2000, 2012), sees informal workers as part of 'non-movements', at times engaged in collective action as 'non-collective actors': 'the shared practices of a large number of fragmented people whose similar but disconnected claims engender important social change in their own lives and in society at large, even though such practices are rarely guided by an ideology, recognizable leadership, or organisation' (Bayat 2010 in 2012, p. 121). During our fieldwork, we realised that much of Bayat's analysis holds true for our case studies and that this insight is important to take into account when discussing organising in Ghana's informal economy.

Indeed, we found that the meaning attached to organisational membership varies widely. Some informal workers did not consider themselves a member, but spoke of 'attending meetings' or 'obeying the leadership', often times without being specific. Others claimed to be members, but could not name the organisation or what it strives for. During one interview, someone even called the leader of an organisation to ask if he was a member-which he turned out to be. Moreover, most people in leadership positions do not keep (written) membership records and the numbers mentioned varied widely, exaggerated or deflated depending on the point they were making. The fact that membership to associations in the workplace is often 'automatic' partly contributes to this vagueness, and 'members' do not necessarily agree with the visions and opinions propagated by their associations.

Bayat's emphasis on unrecognisable leadership in informal workers' organisations also features in our cases. When clear leadership could be identified, what it means to be a 'leader' in terms of requirements and responsibilities was interpreted and contested in a variety of ways, both by members and by leaders. Partly as a consequence of this, decision making processes in these organisations appear difficult to trace. What is clear, however, is that local organisations, kinship groups, and associations all form part of the regulatory powers that actively shape how informal economic activities unfold and workers organise in order to exercise political leverage. With this caveat on the ambiguous nature of informal workers and their organisations in mind, in the following we set out three layers of friction to help probe the dynamics related to the current increase in collaboration with trade unions and international development actors.

\section{Layers of Friction: Organising Across Difference}

Tsing (2005) argues that instead of focusing on similarities, our attention should be focussed on difference, diversity, and divergence, as well as the pragmatic collaborations that ensue from these. Ultimately, she argues, (structural) change comes about when connections across differences are made and 'the goal is not to make difference disappear but to make it part of the political program' (Ibid. 2005, pp. 207, 211). In this section, we engage with these 'politics of working across difference' by discussing how different types of actors are attempting to organise and exercise political leverage across three layers of friction.

The first layer of friction we distinguish arises from the fact that informal workers are competing with each other economically, which fuels friction between them and 
hence also within and between informal workers' organisations. Infighting and fragmentation hamper collective action. Informal workers who lead organisations are usually more affluent, and becoming a leader further increases their status. This is especially so for leaders in transnational informal workers' organisations, because their activities include travelling overseas and public speaking, for which they sometimes receive substantial allowances. Eventually, this alienates leaders from the struggles of their fellow workers, resulting in a rift between members and leaders. Indeed, the majority of workers we spoke to in both locations do not feel heard nor do they believe that they benefit (directly) from what those who (cl)aim to represent them do. As we show below, often the failure to achieve (sustainable) impact can be linked to-personal-conflicts between leaders of an organisation or organisations (see Brown et al. 2010).

As it plays a central role in infighting and fragmentation, we define the partisan system of Ghanaian politics where personal connections and ethnic affiliations tend to play a central role as a second layer of friction (Jockers et al. 2010; Klaus and Paller 2017; Paller 2014). The competition between NDC and NPP is fierce due to Ghana's 'winner takes all' political system, guaranteeing the successful party appointments for government positions on all levels, including the municipality (Whitfield 2009). Partisan politics therefore profoundly shape organising and exercising political leverage by informal workers, particularly those active in marginalised urban areas, since they depend on politicians' goodwill for their activities to continue undisturbed (see Paller 2014; see also Resnick 2011 who makes a similar argument for Zambia). In fact, political parties have created several associations (e.g. for women, car mechanics) in an attempt to harness votes (Campbell 1985; Graham 1985). During the electoral campaigns in 2016, politicians often made promises and gave gifts in attempts to secure votes.

Although sometimes described as passive 'vote banks' and easily persuaded to vote for a politician who promises to improve their plight, informal workers in Ghana are acutely aware of the consequences related to their engagement with the political realm (Lindell 2010). They understand that it provides both problems and opportunities for them: on the one hand, links with politicians - especially around election time-hold the potential to gain access to resources and influence; on the other hand, this can all be lost when one's candidate of choice loses the elections. Choosing sides is risky, but often necessary to obtain resources. This means that a constant balancing act is needed when attempting to get the best in the short run and maintain connections to power and resources over the long term, beyond election cycles. The friction arising from the continued creation of difference through Ghana's volatile partisan political landscape makes organising across these differences extremely challenging. This produces both continuity and change: the two parties alternate, but structural change does not take place.

Partly as a consequence of the political landscape, informal workers' organisations increasingly collaborate with trade unions and international development actors-creating a third layer of friction. The main trade union centres in Ghana are the Ghana Federation of Labour (GFL) and the Ghana Trade Union Congress (GTUC) and they were among the first in Ghana to attempt to organise informal workers. They are sponsored by international development actors to include 
informal workers in their struggle for better working conditions for all workers despite the challenges of finding and defining common interests and goals (Bayat 2012; Rizzo 2013). To this end, GTUC created the Union for Informal Workers' Associations (UNIWA) as an umbrella body, under which it hopes to unite different informal workers' organisations, formalising their affiliation to the union. This development is largely donor driven, as donor funding by international trade union bodies and development organisations makes this activity financially viable for local trade unions struggling with declining membership (fees) in the formal sector. This funding model not only reflects an understanding of informal workers' often precarious economic positions and hence assumed ${ }^{2}$ inability to financially contribute, but also illustrates the increased international interest in the informal economy (Britwum 2013; Chen 2012; Lindell and Ampaire 2016).

In addition to supporting trade unions, international development actors have themselves also become active in organising in the informal economy in Ghana. For example, DANIDA, USAID and the EU fund the Business Sector Advocacy Challenge (BUSAC) initiative in Ghana. Here, too, examples of friction are apparent. In practice, organisations often limit their engagement and financial assistance to groups that fit their pre-designed programmes. This sometimes leads informal workers to present themselves in a different fashion in order to gain access to certain resources. At the time of fieldwork, the leadership of Streetnet Ghana, a branch of the transnational informal workers' organisation Streetnet International ${ }^{3}$, for example, were not actual street vendors themselves (also see Lindell 2010; Brown et al. 2010). On their part, international actors do not always question whether the informal workers' organisations they engage with actually represent the target group they wish to reach, and are able to achieve their commitments.

In the following sections, we explore how the aforementioned layers of friction present themselves in collective action concerning relocation efforts in Makola Market and Suame Magazine.

\section{Makola Market: Relocation Rhetoric}

Makola Market is currently located in the heart of Accra, but when it was built in 1924, the market was operating just outside of town. Over time, Makola kept expanding, drawing ever more customers and vendors to the site. Eventually, its growth caught up with (colonial) city planning and the area became congested.

\footnotetext{
${ }^{2}$ Most of the locally emerged ways of organising do involve the (regular) payment of financial contributions.

3 Transnational informal workers' organisations are different from international organisations such as branches of.

European labour organisations that provide support to partner organisations in developing countries (such as CNV Internationaal), in the sense that they are considered as being transnational collaborative initiatives 'from below'. In practice, however, often international organisations like the ILO and others are behind these 'grassroots' transnational initiatives. For more information on Streetnet International, see http://streetnet.org.za/.
} 
During the severe economic recession of the 1970s and 1980s, several parts of Makola were destroyed by the government in an attempt to regulate the economy and find a scapegoat for the steep price rises and inflation (Grant and Yankson 2002, p. 68; Robertson 1983, p. 469). In 1986, however, (the now late) President Rawlings changed his mind and allowed market vendors who had started selling their goods from a parking lot to relocate to an old government bus terminal and former lorry park. They would be obliged, as they had been in previous locations, to pay rent for their stalls and daily fees to the city council, the Accra Metropolitan Assembly (AMA). This former lorry park is now known as the '31st December Market', referencing the opening date of the market as well as the 31st December Women's Movement-an organisation closely affiliated to Rawlings' party, the (present-day) NDC.

Stories about the imminent relocation of Makola's 31st December Market have circulated since its inception. Today, it is clear that the market's infrastructure has not been well maintained. Buildings are dilapidated and traders and their goods have spilled out onto the surrounding streets due to lack of space. The electricity network that provides lights and fans in the market stalls has been boosted beyond its capacity and some stalls are beginning to collapse. AMA therefore deems 'modernisations' necessary in order to include and improve services such as safe lighting, a working sewage system, a waste disposal site, a police station, a day-care centre, a bank, and a restaurant. Controversially, the city council contends that in order to modernise the market, traders will have to relocate for (re)construction to commence.

After failed relocation attempts in the 1980s and 1990s, AMA decided that in the 2010s, the process should be participatory. Traditionally, markets in Ghana are made up of traders who organise themselves according to the commodity they sell. These commodity associations provide informal welfare to their members and are led by commodity queens. Membership to these associations is automatic: everyone who sells in the market is considered a member and required to pay (a relatively small amount of) dues. From among the commodity queens, a marketplace queen is chosen and she subsequently governs the market in its entirety, allocating stalls to traders, negotiating price tariffs, settling (internal) disputes and representing the market to municipal authorities, albeit not in a formal bureaucratic capacity (see AsomaniBoateng 2016; Clark 1997, 2010). Most market queens are deeply implicated in the existing patronage networks that govern urban Ghana (Paller 2014): aligning themselves with a political party is a way to acquire influence and resources that benefit the market and its traders (cf. Clark 1997). At the time of fieldwork, Makola's 31st December acting market queen was linked to the 31st December Women's Movement and the NDC party.

In view of the participatory nature of the relocation process, Makola's 31st December market queen was invited to several meetings and shown plans for the reconstruction. She was impressed with the proposed seven storey building: it doubles the selling spaces without expanding the surface area of the market, and it aims to attract more customers due to its 'multipurpose' nature. Modernising the market would also mean better working conditions for the workers the market queen represents. Describing AMA as her 'landlord', she welcomed improvements to the structures: 'if they collect money, you have to see improvements'. Moreover, she believed that the new building will generate greater popular support and better sales. For this 
reason, several years ago during NDC rule, the market queen agreed to temporary relocation.

In order to help her own clientele, the queen offered to handle the registration of the current traders herself: 'we know our members'. Using their AMA licence, all traders who rent a shop in Makola's $31^{\text {st }}$ December Market had to register with the queen. With this registration exercise, the municipality (cl)aims to ensure that there will be new stalls assigned to all registered traders during the relocation and in the new building once construction is complete. In practice, however, many traders do not have their name on the AMA licence they use: the original licence holder may have passed away, or traders rent stores licenced to others. Traders pay this rent to AMA, but, traditionally, it is the queen who decides who can sell in the market. The collaboration and at times conflation of these two authorities fuelled rumours about the queen conspiring with the AMA to 'sell' the market and make a profit out of the registration and relocation scheme. Several traders stated that only NDC supporters were allowed to register and that others had to pay hefty fees, if they were allowed to register at all-something the queen denied. Moreover, during election time, rumours circulated that a vote for NPP meant the relocation plans would be abandoned. This appears to have prompted AMA to put the relocation project 'on hold' so as not to antagonise potential voters.

Many traders worried that they would not be able to afford the increased tariffs for the new stalls after (temporary) relocation. Others, such as a pig feet and fresh fish trader, believed that their commodities would not fit in a modern shopping mall environment. The idea of having to set up shop above ground floor level also did not appeal to everyone: 'it won't help us: people don't like to climb up', a vice-president of a commodity association stated. Moreover, many traders fear that the relocation will become rather permanent. Although none of them denounces the need for renovations and improvements in the current structures, most traders appear reluctant to relocate. Since their traditional representative, the market queen, is in favour of relocating, traders have increasingly looked for other allies to voice their concerns.

Since the early 2000s, one of Ghana's trade unions (GTUC) has been active in Makola Market, mainly through their collaboration with a trader who firmly opposed the political preference of the market queen (Hendriks 2017). After NDC lost the elections in 2000, this cloth seller increased her organising efforts and registered the 'New Makola Market Traders Union'. The union grew during NPP's time in office, but when NDC returned to power in 2008, its (political) network somewhat subsided. Outside of the market, they connected with several international donors and joined forces with transnational informal workers' organisations, including Streetnet International and WIEGO (Women in Informal Employment Globalizing and Organizing). ${ }^{4}$ Later, they also became a founding member of GTUC's Union for Informal Workers' Associations (UNIWA), placing themselves at the forefront of trade union organising in Makola Market. Interestingly, the union does not present a strong opinion on the potential relocation. Because its leadership appears linked

\footnotetext{
4 Transnational informal workers' organisations are often connected to each other through global networks of affiliation.
} 
to NPP, a change in government could mean that they would equally support (temporary) relocation as part of the-then NPP dominated-AMA plans. During the 2016 election, the union continued to organise activities, but most traders referred to them as a small group of people, only doing 'things with the NGO's and so on', led by somebody who 'is nobody' in the traditional hierarchy of the market. This conflict between the market queen and the union ('s president) discouraged traders from becoming members. Despite the distraction of Makola's everyday affairs, the union's affiliation to international donors and organisations provided hope for those who did not wish to relocate.

Both UNIWA and WIEGO focus on the importance of the rights and interests of the informal workers currently active in Makola. Yet, they are both reluctant to renounce potential relocation altogether as this could improve working conditions. Streetnet Ghana emphasises the importance of not ending up on the streets during and/or after relocation, but it also campaigns for an increase in the number of available stalls. The former could be taken as an argument against relocating (temporarily), but the latter is a prominent part of the envisioned new building. The more affluent traders appeared eager to (temporarily) relocate and subsequently continue their business in an improved environment, but by the end of fieldwork, it remained unclear whether relocation would actually take place. The only certainty appeared to be the continuation of the relocation rhetoric.

\section{Suame Magazine: Competitive Relocation}

In Kumasi, the original car repair cluster arose in the 1930s close to a colonial weapons magazine near present-day Kumasi Zoo (Nyaki Adeya 2008; Iddrisu et al. 2012). Due to its rapid expansion, workers were moved in the 1950s and 1960s to its current location in the suburb of Suame, taking the term 'magazine' with them. Efficient subcontracting between different professional groups associated with vehicle repair enabled local artisans to compete favourably with private garages and the cluster grew into the largest industrial cluster of informal workers in West Africa (Waldman-Brown et al. 2013, p. 1). However, workers have complained in recent decades that there is no sufficient work anymore, that the area is congested, and the infrastructure dilapidated. Subsequently, there have been calls to relocate to an area outside of Suame (McGrath et al. 1994).

The control of land became, and still is, the main function of the Magazine Mechanical Association (MMA), an informal workers' organisation set up in 1957 to keep track of property parcelling and ownership; making it the oldest association of Suame Magazine. The area under its control belongs to the King of the Ashanti region, but the responsibility to collect leases and mediate in conflicts was given to the MMA, which retains a percentage of the revenue. The Ghanaian National Association of Garages (GNAG) was established in 1982 with Rawlings' direct support, creating additional administrative 'zones' in Suame Magazine (Waldman-Brown et al. n.d.). However, definitions of 'lease' and 'ownership' were left precariously ambiguous and newcomers erected their workshops illegally in makeshift shacks on the fringes of Suame Magazine. This has exacerbated the long-standing congestion 
of Suame Magazine and makes the desire to relocate more acute. It even prompted the establishment of another informal workers' organisation in 2006, explicitly focussed on relocation, largely funded by DANIDA and BUSAC: the Suame Magazine Industrial Development Organisation (SMIDO).

SMIDO has been unchallenged in its ability to create (inter)national awareness about Suame Magazine and the challenges its workers face. Its founders argued that a new site had to be procured where a modern 'industrial village' could be established with clean roads, waste management sites, and modern equipment. Moreover, SMIDO was structured as an umbrella organisation where all the existing organisations in Suame Magazine would have equal power and could pool their strengths: all their members would become automatic SMIDO members. A hierarchical structure was established where representatives from all organisations make up an executive committee, which then elects a president. As a result of a history of failed initiatives, there was a strong sense that political parties would not be able or willing to assist workers in Suame Magazine. Indeed, time and again, politicians expressed their support for SMIDO's projects, but none of them followed through when in power. During the run-up to the presidential elections in November 2016, the NPP candidate visited the area and promised to assist SMIDO in transforming Suame Magazine into an 'industrial hub' with modern infrastructure and employment opportunities (Ofosu-Afriyie 2016).

Another authority that could assist in effecting the relocation is the local government. However, the informal workers in Suame Magazine and the Kumasi Metropolitan Assembly (KMA) have an ambivalent relationship, which appears to be stuck in a vicious circle: workers often refuse to pay taxes because they do not believe the government will help them, while the government is reluctant to intervene precisely because workers neglect paying their taxes. KMA has previously approached both SMIDO and GNAG to collect taxes on its behalf while retaining a certain percentage. While tax collection increased only marginally, it was more than anything the KMA had ever managed to collect. As a result, many within the KMA are not in a hurry to see the workers move to a site outside of their jurisdiction, as this would result in a loss of (in)direct revenue. It seems that if there is no political capital to be mined from campaigning in the area or by 'supporting' initiatives, little attention is given to Suame Magazine by politicians and the (national) government.

For relocation to take place, SMIDO pursued the (financial) support of external partners. The aforementioned BUSAC fund was initially the sole provider of financial support to the organisation (seven million GHC, more than 1.2 million Euros) as SMIDO's estimate of the payment of membership dues proved too ambitious. A media campaign was launched and several publications were drafted in order to spread awareness about SMIDO (SMIDO 2007, 2012, 2013). DANIDA and the Kumasi University of Science and Technology (KNUST) provided some financial and/or logistical support and United Pensions Trust (UPT) joined as an investor. Subsequently, the SMID fund was set up as a forum for investors. However, even before a relocation site was identified, conflict between SMIDO's member organisations broke out.

At the core of the disputes was the issue of who was going to be elected the new leader of SMIDO. The first president fell from grace when he invested much of his 
own money in the organisation and allegedly adopted an autocratic management style. He was suspected of campaigning for the NDC on behalf of SMIDO, in contravention of their politically neutral stance. He was thus voted out and replaced. When he left, however, he locked the doors of the meeting room, which remained locked at the time of fieldwork. Concomitantly, the GNAG left SMIDO because it felt that it, as the most established organisation, should be at its helm. Interestingly, they were experiencing similar problems with their leader at the time, who was said to be campaigning for the NPP. He supposedly prevented the NDC from campaigning in the area and locked the meeting rooms when he was ousted by pro-NDC members following the victory of NDC in 2008. The GNAG also claimed that it had thought about relocation before SMIDO and that it had even procured property elsewhere for this purpose. In general, discussions about moving to new sites remain vague and workers are fed up with empty promises of relocation.

Yet, while these conflicts made progressing the relocation difficult, the plan was not abandoned and DANIDA initially still supported SMIDO in its search. A potential site was identified in a neighbouring district, about half an hour's drive north of Kumasi. The local government of this area welcomed the idea of establishing a local 'magazine' which would bring economic development. Fed up with waiting and having to satisfy their members, who were starting to lose faith in the relocation scheme, the SMIDO executives asked UPT to acquire the land on their behalf and transfer it back to them at a later date. UPT agreed on one condition that the SMIDO fund be turned into a social security fund, obliging members to subscribe to insurance in order to get access to a plot in the new site. This gave UPT tremendous power over SMIDO: it virtually took over the planning of the new site.

This deal resulted in DANIDA disengaging from SMIDO, as the title deed to the land would now be in the name of a private organisation, which could not be supported with foreign aid money. UPT, however, was only able to come up with a fraction of the money necessary to acquire the site. Moreover, many workers were concerned about the remote location of the new site or the rent that will have to be paid for 'modern infrastructure.' As in Makola, many also wondered why it would be up to SMIDO to decide who gets to move and who does not. While plans remain vague and organisations have lost much of their popularity, informal workers' organisations in Suame Magazine continue to exercise political leverage and attract international partners to join their struggle. This, however, only adds to the complexity and generates plenty of friction. In the next section, we examine how our case studies fit with our previously laid out framework.

\section{Discussion}

Increasingly so, trade unions, international development actors, and transnational informal workers' organisations are attempting to assist informal workers in Ghana to organise and exercise more political leverage. However, the collaborations across difference between informal workers, informal workers' organisations, trade unions, international development actors, transnational informal workers' organisations, and Ghana's partisan political realm have proven to be fraught with friction. Our case 
studies underline the complexities that arise when attempting to organise in relation to potential relocation. On this basis, we distinguished three different but entangled layers of friction that cause this specific dynamic: friction among informal workers, friction in the political realm, and friction between informal workers' organisations and their partners.

In both places, a multitude of informal workers' organisations has been active and this has led to infighting, fragmentation, and conflicting claims of legitimacy to rule, represent, extract, and control the revenue involved. Political ties play a decisive, yet largely unpredictable and divisive role in organising, gaining access to resources, and creating political leverage in both Kumasi and Accra. In Suame magazine, for example, an unexpected change in the outcome of elections led to the ousting of particular individuals, who attempted to sabotage operations on their way out. To some extent, Suame Magazine is widely regarded as a NPP-area, whereas Makola's 31st December Market is associated with the NDC; they are thus approached differently by these political parties and also depending on who is in power-be it that the NPP and NDC rivalries play out in both localities' informal workers organisations. Makola Market is for its part located close to the seat of the municipal authorities and national government in Accra and thus also often visited by politicians, trade unions, and international development actors. Suame Magazine is much less frequented partly due to the high travel costs associated with the long journey from Accra. While both trade union centres in Ghana claim to have organised informal workers in Suame Magazine, their activities were unsuccessful, short-lived, and largely unknown to the majority of the workers. Despite the union and UNIWA members being increasingly active in Makola Market, a similar lack of awareness presents itself here.

Informal workers' organisations also have various relationships with their respective municipal authorities. AMA and, to a lesser extent, KMA function as 'landlords' who are responsible for the maintenance of the structures. In return, they (in theory and sometimes practice) receive daily fees and annual rent from the informal workers who use these. Yet, in the case of Makola Market, it is the AMA calling for relocation of the market. In contrast, KMA collaborates with some of the informal workers' organisations in Suame Magazine with respect to tax and fee collection, but they seem reluctant to let Suame Magazine relocate to an area outside their (financial) jurisdiction. Moreover, in contrast to Makola's 31st December Market, traditional leaders exert great influence in Suame Magazine as they also derive financial gains from their role as 'landlords'. Makola's market queen also benefits from her position as a 'traditional' authority, but it seems unlikely that her role will disappear after the relocation.

In order to escape these localised dynamics, we have seen how informal workers' organisations seek out transnational collaboration. International organisations have for their part also increasingly sought to become involved with informal workers' organisations. While transnational cooperation is evidently eagerly sought after by local organisations, we have shown throughout our case studies that the involvement of international organisations also features as a catalyst for the layers of friction to become further entangled eventually leading to initiatives imploding. For example, the initial financial support of DANIDA urged SMIDO to look for a potential new 
relocation site; yet the first and second layer of friction soon resulted in infighting and political mobilisation, causing the initiative to come to a standstill and DANIDA to end its support. The involvement of transnational organisations is then not able to quell personal rivalries, competition with other interested parties, or to navigate the political context without increasing tensions.

What is clear is that these three layers of friction are deeply entangled in livedreality and hence fuel further differentiation in daily interactions. Collaborations between informal workers' organisations, trade unions, and international development actors aim to reconcile differences and create a common basis, but the differences are sometimes so big — and politicised — that it becomes challenging to build on them. Our two cases show that collaborations across differences in the informal economy constantly emerge, and most recently in the shape of transnational collaborations. While promising vehicles for change to many, the initiatives tend to eventually stagnate and are productive merely in the sense of perpetuating or further entrenching the status quo. The precarious nature of informal work combined with the sheer number of actors involved and the multiple layers of friction make the translation of friction's productive element into (long-term) tangible change(s) challenging. Taking the creation of SMIDO, it was established due to differences of opinion and dissatisfaction with the existing organisations. This friction has led to a 'new arrangement' of power, because now SMIDO is also a force to be reckoned with (Tsing 2005, p. 4). Significantly, however, the emergence of new organisations, generated by friction, generates more friction. Friction in this sense mainly produces continuity, slightly changing the status quo initially, but ultimately further entrenching the same dynamics in the long run. Short-term connections that do arise subsequently succumb to the magnitude of all interacting layers of friction before being able to effectuate structural change.

It then appears that friction, 'the awkward, unequal, unstable, and creative qualities of interconnections across difference' (Tsing 2005, p. 4), although abundantly present, has not led to long-lasting re-arrangements of power when it comes to organising in Ghana's informal economy. Both relocations, despite having been 'on the agenda' for the past decades, have not (yet) fully taken place. ${ }^{5}$ This is, of course, to the benefit of some and to the detriment of others. Indeed, these challenges should not be taken to mean that nobody benefits from these (attempts at) collaborations: 'collaborations create new interests and identities, but not to everyone's benefit' (Tsing 2005, p. 13, emphasis in original). Friction, then, produces both continuity and change, but generally entrenches the logic of (a few) 'winners' and (many) 'losers'. As we have shown, the politics of relocation as played out across the layers of friction in Suame Magazine and Makola's 31st December Market have been defined by the involvement of transnational organisations along these lines. Structural change is not achieved, but new (transnational) informal workers'

\footnotetext{
${ }^{5}$ Recent news reports indicate that AMA has rehabilitated Makola's $31^{\text {st }}$ December Market: https:// citinewsroom.com/2019/05/reconstruction-of-31st-december-makola-market-to-begin-this-week/ (last accessed 07-01-2021) and https://ama.gov.gh/news-details.php?n=Nzk4czBxNnNzb282ODBuNjUxc HJwNzBybzJyODQwNzU2MjQxMm84MQ (last accessed 07-01-2021).
} 
organisations continue to emerge and some groups of informal workers do benefit in some respects. More research is needed to find out why certain groups of informal workers consistently 'lose out' and how organising (in the informal economy) can become more inclusive.

\section{Concluding Remarks}

What do the foregoing observations yield in view of the theme of this special issue, i.e. policies for inclusive development? First of all, we want to stress that informal workers, rather than anonymous masses waiting to be 'included', are active and knowledgeable agents who deal with the challenges they encounter in ways that are well suited for the specific contexts in which they live and work. Second, as we have tried to show, striving for inclusive development is not a straightforward activity, but rather a fragmented process made up of smaller processes and struggles, shaped by diverse agendas and possibly conflicting interests. This means that (understanding) local strategies and dynamics should be the starting point for thinking about fostering inclusive development. This also means that, instead of glossing them over because they seem too complex and loaded, the relational and political aspects as well as their consecutive frictions in processes and struggles related to inclusive development should be taken as building blocks for policy recommendations. We would like to use the remainder of this concluding section to illustrate what this could look like for our case studies, by providing tailored rather than one-size-fitsall suggestions that could enable positive change.

For our case studies, it would be important to start from the recognition that often there are discrepancies in motives for collective action between leaders and members of informal workers' organisations, that partisan politics and cooptation by political parties influence strategies and outcomes to a profound degree, and that international donors very often have a conflict-stimulating impact on power hierarchies between groups and organisations of informal workers. Based on these observations, our recommendations to informal workers would include the following: accept that you have different (and sometimes opposing) interests, you can still collaborate on issues of shared concern; make your needs heard, unity in action makes you strong; reach out to people and organisations that are responsive to your needs; promises of people/organisations do not count, only real action does!

Our recommendations to leaders of (informal) workers' organisations, who often aim to raise membership in order to gain power are the following: identify needs on the ground and support collective action concerning those needs; do not so much focus on increasing membership but rather on successful action; less bureaucratic and more dynamic, agile, organisations tend to be more effective in seizing opportunities; as a(n unintended) consequence, membership may increase because of visible, effective action.

In the same vein, our recommendations to international partners include the following: stimulate unity in action and collaborative platforms rather than unity of organisation; be critical about the competitions you are engaged in yourself and 
try not to have these influence your actions in partner countries; instead of offering technical training (which presupposes that people lack technical knowledge and skills), rather facilitate (relational, political, contextual) analysis and mutual learning (for instance concerning un/successful collective actions).

In sum, our research suggests that differences in power, interests, perspectives, and agendas, and the friction that they produce should be not glossed over but rather taken as the point of departure for thinking about potential 'win-win' processes, as well as barriers to these, over diverse spans of time and levels of interaction. Such win-win opportunities may be rather small scale or limited, but as we have also underlined, inclusive development is a fragmented process built by multiple struggles and processes, involving changing coalitions of interests and partnerships. We propose to humbly embrace this quality.

Acknowledgements We would like to thank the Netherlands Ministry of Foreign Affairs for having funded the research. We would furthermore thank all people in Accra and Kumasi who have so generously shared their knowledge and insights with us. In particular, we would like to thank our research assistants, Pamela Osei-Boateng (Accra) and Nyantakyi Osei-Adu and Nancy Narkie Nartey (Kumasi).

Author Contributions All authors contributed equally to the writing of this article.

\section{Declarations}

Conflict of interest On behalf of all authors, the corresponding author states that there is no conflict of interest.

Open Access This article is licensed under a Creative Commons Attribution 4.0 International License, which permits use, sharing, adaptation, distribution and reproduction in any medium or format, as long as you give appropriate credit to the original author(s) and the source, provide a link to the Creative Commons licence, and indicate if changes were made. The images or other third party material in this article are included in the article's Creative Commons licence, unless indicated otherwise in a credit line to the material. If material is not included in the article's Creative Commons licence and your intended use is not permitted by statutory regulation or exceeds the permitted use, you will need to obtain permission directly from the copyright holder. To view a copy of this licence, visit http://creativecommons.org/licen ses/by/4.0/.

\section{References}

Asomani-Boateng, R. 2016. Local Networks: Commodity Queens and the Management of Organic Solid Waste in Indigenous Open-Air Markets in Accra, Ghana. Journal of Planning Education and Research 36 (2): 182-194.

Bayat, A. 1997. Un-Civil Society: The Politics of the 'Informal People.' Third World Quarterly 18 (1): $53-72$.

Bayat, A. 2000. From 'Dangerous Classes' to 'Quiet Rebels'. Politics of the Urban Subaltern in the Global South. International Sociology 15 (3): 533-557.

Bayat, A. 2012. Politics in the City-Inside-Out. City \& Society 24 (2): 110-128.

Benjamin, N., and A.A. Mbaye. 2012. Les entreprises informelles de l'Afrique de l'ouest francophone: Taille, productivité et institutions. Africa Development Forum. Washington, DC: World Bank and Agence Francaise de Développement. 
Britwum, A.O. 2013. Market Queens and the Blame Game in Ghanaian Tomato Marketing. In The Food Crisis: Implications for Labor, ed. C. Scherrer and D. Saha, 53-71. Munchen: Rainer Hampp Verlag.

Brown, A., M. Lyons, and I. Dankoco. 2010. Street Traders and the Emerging Spaces for Urban Voice and Citizenship in African Cities. Urban Studies 47 (3): 666-683.

Campbell, J. 1985. Ideology and Politics in the Markets of Ghana. Canadian Journal of African Studies 19 (2): 423-430.

Chen, M.A. 2012. The Informal Economy: Definitions, Theories and Policies. WIEGO Working Paper 1.

Clark, G. 1997. Market Queens. Innovation within Akan Tradition. Annals of the New York Academy of Sciences 810: 173-201.

Clark, G. 2010. Gender Fictions and Gender Tensions Involving 'Traditional' Asante Market Women'. African Studies Quarterly 11 (23): 43-66.

Cloutier, M., B. Harborne, D. Isser, I. Santos, Indhira, and M. Watts, 2021. Social Contracts for Development : Bargaining, Contention, and Social Inclusion in Sub-Saharan Africa. Washington, DC: World Bank and Paris: Agence française de développement.

Ferguson, J., 1994. The Anti-Politics Machine. Development, Depoliticization, and Bureaucratic Power in Lesotho. Minnesota: University of Minnesota Press.

Ghana Trade Union Congress (GTUC). 2009. 'The Labour Market in Ghana. A Descriptive Analysis of the Labour Market Component of the Ghana Living Standards Survey'. Research paper 2009/01. Kwabena Nyarko Otoo, Clara Osei-Boateng and Prince Asafu-Adjaye. ms.

Gillespie, T. 2015. Accumulation by Urban Dispossession: Struggles Over Urban Space in Accra, Ghana. Transactions of the Institute of British Geographers 41: 66-77.

Graham, Y. 1985. The Politics of Crisis in Ghana: Class Struggle and Organisation. 1981-84. Review of African Political Economy 34: 54-68.

Grant, R., and P. Yankson. 2003. City Profile ACCRA. Cities 20 (1): 65-74.

Green, D. 2018. How Change Happens. Oxford: Oxford University Press.

Gupta, J., N. Pouw, and M. Ros-Tonen. 2015. Towards an Elaborated Theory of Inclusive Development. European Journal of Development Research 27: 541-559.

Hart, K, 2009. On the Informal Economy: The Political History of an Ethnographic Concept. CEB Working Paper 09/042.

Hendriks, T. 2017. Collaboration and competition: market queens, trade unions and collective action of informal workers in Ghana's Makola market. Interface: A Journal for and About Social Movements 9 (2): 162-187.

Iddrisu, A., Y. Mano, and T. Sonobe. 2012. Entrepreneurial Skills and Industrial Development: The Case of a Car Repair and Metalworking Cluster in Ghana. Journal of the Knowledge Economy 3: 302-326.

ILO. 2013. ILO Strategy for Action Towards Making Decent Work a Reality for Domestic Workers Worldwide. Geneva: International Labour Organisation.

ILO. 2021. Extending Social Protection to Migrant Workers, Refugees, and their Families: Guide for Policymakers and Practitioners. Geneva: International Labour Organisation.

Jockers, H., D. Kohnert, and P. Nugent. 2010. The Successful Ghana Election of 2008: A Convenient Myth? Journal of Modern African Studies 48 (1): 95-115.

Kamete, A.Y., and I. Lindell. 2010. The Politics of 'Non-Planning' Interventions in African Cities: Unravelling the International and Local Dimensions in Harare and Maputo. Journal of Southern African Studies 36 (4): 889-912.

Klaus, K., and J.W. Paller. 2017. Defending the city, defending votes: Campaign strategies in urban Ghana. Journal of Modern African Studies 55 (4): 681-708.

Kraus, J. 1991. The Struggle Over Structural Adjustment in Ghana. Africa Today 38 (4): 1-19.

Lindell, I. 2009. 'Glocal' Movements: Place Struggle and Transnational Organising by Informal Workers. Geografiska Annaler: Series b, Human Geography 91 (2): 123-136.

Lindell, I. 2010. Africa's Informal Workers. Collective Agency, Alliances and Transnational Organising in Urban Africa. London: Zed Books.

Lindell, I., and C. Ampaire. 2016. The Untamed Politics of Urban Informality: "Gray Space" and Struggles for Recognition in an African City. Theoretical Inquiries in Law 17: 257-282.

Lyon, F. 2003. Trader Associations and Urban Food Systems in Ghana: Institutionalist Approaches to Understanding Urban Collective Action. International Journal of Urban and Regional Research 27 (1): 11-23. 
McGrath, S., K. King, F. Leach, and R. Carr-Hill. 1994. Education and Training for the Informal SectorEducation Research Paper No. 11 (Volume II). London: Department for International Development.

Munck, R. 2013. The Precariat: A view from the South. Third World Quarterly 34 (5): 747-762.

Nyaki Adeya, C. 2008. The Suame Manufacturing Cluster in Ghana. In Knowledge, Technology, and Cluster-Based Growth, ed. D. Zhihua Zeng. Washington, D.C.: World Bank.

Ofosu-Afriyie, M. 2016. 'Suame will be an industrial hub-Alan K. tells artisans. https://rawgist.com/ suame-will-industrial-hub-alan-k-tells-artisans/. Accessed 02 February 2018.

Osei-Boateng, C. \& Ampratwum, E. 2011. The Informal Sector in Ghana. Friedrich Ebert Stifftung.

Overå, R. 2007. When Men Do Women's Work: Structural Adjustment, Unemployment and Changing Gender Relations in the Informal Economy of Accra, Ghana. The Journal of Modern African Studies 45 (4): 539-563.

Paller, J.W. 2014. Informal Institutions and Personal Rule in Urban Ghana. African Studies Review 57 (3): $123-142$.

Reinders, S., M. Dekker, F.V. Kesteren, and L.W. Oudenhuijsen. 2019. Synthesis Report: Inclusive Development in Africa. Leiden: INCLUDE.

Resnick, D. 2011. In the shadow of the city. Africa's urban poor in opposition strongholds. Journal of Modern African Studies 49 (1): 141-166.

Rizzo, M. 2013. Informalisation and the end of trade unionism as we knew it? Dissenting remarks from a Tanzanian case study. Review of African Political Economy 40 (136): 290-308.

Robertson, C. 1983. The Death of Makola and Other Tragedies. Canadian Journal of African Studies 17 (3): 469-495.

Roy, A. 2005. Urban Informality: Toward an Epistemology of Planning. Journal of the American Planning Association 71 (2): 147-158.

Sindzingre, A. 2006. The Relevance of the Concepts of Formality and Informality: A Theoretical Appraisal. In Linking the Formal and Informal Economy: Concepts and Policies, ed. B. Guha-Khasnobis, R. Kanubr, and E. Ostrom, 58-74. Oxford: Oxford University.

SMIDO. 2007.SMIDO Industrial Development Policy Blueprint. Establishing the case for Suame Magazine Industrial Development in Ghana. s.d. s.l.

SMIDO. 2012. SMIDO-Otumfuo Industrial Centre Project. Establishing the case for a Home-Grown Investment Model. s.d. s.l.

SMIDO. 2013. The Regional Investment Gateway Project. Promoting Local-Content Investment \& Policy for Industrialization. s.d. s.l.

Thiel, A. 2015. Heterotemporal convergences: Travelling significations of order and their adaptations in the claimsmaking strategies of Accra's Makola market traders. PhD-thesis, University of Aberdeen.

Theron, J. 2010. 'Informalization from Above, Informalization from Below: The Options for Organisation. African Studies Quarterly 11 (2\&3): 87-105.

Tsing, A.L. 2005. Friction. An Ethnography of Global Connection. Oxford: Princeton University Press.

Utz, R.J. 2021. Archipelagic Economies: Spatial Economic Development in the Pacific. Washington, DC: World Bank.

Waldman-Brown, A., et al. n.d. Fabbing for Africa's informal sector. ms.

Waldman-Brown, A., G. Yaw-Obeng, and Y. Adu-Gyamfi. 2013. 'Innovation and stagnation among Ghana's technical artisans'. Paper presented at the 22nd Conference for the International Association of Management of Technology (IAMOT) 2013. Science, Technology and Innovations in the Emerging Markets. April 14-18, 2013, Porto Alegre, Brazil.

Whitfield, L. 2009. Change for a better Ghana': Party Competition, Institutionalization and Alternation in Ghana's 2008 Elections. African Affairs 108 (433): 621-641.

Publisher's Note Springer Nature remains neutral with regard to jurisdictional claims in published maps and institutional affiliations. 